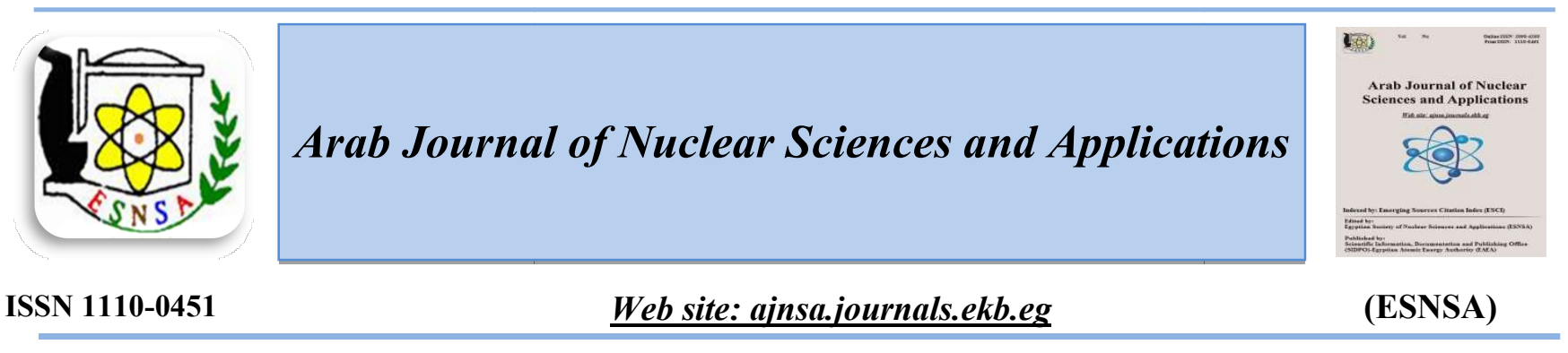

\title{
Spectroscopic Analysis of Irradiated Natural Quartz and ESR Dating Aspects
}

\author{
Said M. Kassem ${ }^{1}$, A. M. Rashad ${ }^{2 *}$,G. S. M. Ahmed ${ }^{3}, \operatorname{RamyAmer~Fahim}^{1}$, S. M. Salem ${ }^{3}$, S. Ebraheem $^{1}, A$. G. $^{2}$ \\ Mostafa $^{3}$ and A.I. Helal ${ }^{*}$ \\ ${ }^{I}$ Department of Radiation Protection and Dosimetry, National Center for Radiation Research and Technology \\ (NCRRT), Egyptian Atomic Energy Authority (EAEA), Cairo, Egypt \\ ${ }^{2}$ Department of Accelerators and Ion Sources, Nuclear Research Center (NRC), Egyptian Atomic Energy Authority \\ (EAEA), Egypt \\ ${ }^{3}$ Department of Physics, Faculty of Science, Al-Azhar University, Cairo, Egypt \\ ${ }^{4}$ Department of Experimental Physics, Nuclear Research Center (NRC), Egyptian Atomic Energy Authority (EAEA), \\ Egypt
}

\begin{abstract}
Received $15^{\text {th }}$ Jan. 2020 In this study, a spectroscopic characterization was conducted for natural milky quartz sample from Accepted $11^{\text {th }}$ June 2020 Wadi Araba at the Egyptian Eastern Desert. This quartz material was studied using scanning electron microscope (SEM), X-ray powder diffraction (XRD), UV-visible spectrophotometer (UV-vis), Fourier transform infrared spectrometer (FTIR), X-ray fluorescence spectrometer (XRF), inductively coupled plasma optical emission spectrometer (ICP-OES) and electron spin resonance (ESR) technique. In the current study, raw samples were used as-received and treated under controlled gamma irradiation conditions. The results revealed that gamma radiation had a slight influence on the color of the milky quartz samples. XRF and ICP-OES were used to recognition the elemental composition of the raw sample. The ESR spectrum accomplished at room temperature displays intrinsic defects such as Aluminium (AI) trap center. Furthermore, with increasing the additive doses, the area under the dose response curve increases as a polynomial function, which is applicable for ESR dating aspects.
\end{abstract}

Keywords: ESR dating, Natural Quartz, Gamma-ray Irradiation, Natural dosimeter, additive dose method;

\section{Introduction}

$\mathrm{SiO}_{2}$, the abundant crystalline form of quartz under ambient conditions, is one of the most dominant minerals in earth's surface. The natural quartz could be found in sediments minerals (sandstones, quartzites, and mudstones, etc) [1], particularly in the eastern desert of Egypt. Moreover, natural quartz is mainly used as the raw material for the hydrothermal synthesis of cultured quartz. The natural quartz remains as a criticalmatter for scientific study [2]. Many studies were conducted to understand the radiation effects on quartz by spectroscopic monitoring of the radiation-induced changes at the point defects at quartz configuration [3], every $\mathrm{Si}$ atom in quartz is bonded to four oxygen atoms and a single oxygen atom is bonded to two $\mathrm{Si}$ atoms. This order produces a network of combined $\mathrm{SiO}_{4}$ units with a crystalline structure referring to the trigonaltrapezohedral state of the rhombohedral subsystem and a hexagonal lattice. The space groups that represent left and right quartz (in a right-handed hexagonal system) are $\mathrm{P} 3_{1} 21$ and $\mathrm{P} 3_{2} 21$ and the Laue class is D3d. There is neither a symmetry plane nor a center of

Corresponding author:rashad119@yahoo.com

DOI: 10.21608/ajnsa.2020.22502.1321

CScientific Information, Documentation and Publishing Office (SIDPO)-EAEA 
symmetry. The crystal structure of quartz donates two types of parallel channels unequal in diameter. The $\mathrm{SiO}_{2}$ is bounded by both a half-covalent bond and half-ionic bond at lattice crystal and polymorphous i.e. low\& high quartz, cristobalite, tridymite, etc. The natural quartz as a gemstone is a unique kind of silicate that is stationary at barometrical pressures and temperature. In various natural quartz investigations, the irradiation or heating method was a way to monitor the modulation of both intrinsic and impurity defects (the point defects) [1]. During crystallization, the impurities and structural defects are regularly joined as charge compensated diamagnetic defects. Natural radioactivity and the electron irradiation during experiments, affect the conversion of diamagnetic precursors into paramagnetic centers [4].

Quartz is utilized under various scopes, including dosimetry, age dating, and electronics [5]; [6]. Furthermore, it is applicable to use in jewelers [7]; [8]. Both polished and natural quartz include impurities, normally Iron $(\mathrm{Fe})$ and Aluminium (Al), which may hold each the silicon place or a hole site in the crystal structure. Some of these impurities are trivalent such as $\mathrm{Fe}^{3 \pm}$ and $\mathrm{Al}^{3 \pm}$ while silicon is tetravalent $\mathrm{Si}^{4 \pm}$, the point defect produced when they substitute for Si requires a charge set by a positive-charged item called a charge compensator including alkalis in quartz as $\left(\mathrm{H}^{+}, \mathrm{Li}^{+}\right.$, and $\mathrm{Na}^{+}$) [9]. Besides, the holes generated through quartz irradiation can also act as charge compensators, which are usually present at neighboring localities due to the strong Coulomb force among them [10]. During the crystallization process, the quartz fragments usually accommodate solid and fluid embodiments. If these embodiments exist at high quantities (milky quartz sample), they will have a great impact on chemical characteristics of raw quartz, as it deposited into crystals, also it is difficult to eliminate especially the hydrothermal type [11].

The Electron Spin Resonance (ESR) method is one of the common dating methods. The most appropriate substance for archaeological dating by ESR is quartz [12]; [13], although, it is a complicated process that involves paramagnetic centers and optical bleaching and is not completely understood. In this study, focus will be on the ultimate paramagnetic centers utilized for dating deposits, which is $\mathrm{Al}$ hole center that cannot be wholly zeroed if bleached.
The additive dose-response curve is ordinarily established to be the top boundary of ESR dating technique, which is associated with the specific saturation dose growth when the lifetime of ESR signal is quite high. The ESR dating of quartz has a great potential to extend the age limit rather than the luminescence dating. No enough studies have calculated saturation dose values to estimate the upper limit of quartz ESR signals [14]; [15]; [16].

Aitken et al., [17] reported that if the thermal decay permissible is $10 \%$, the thermal lifetime must be at least 5 times the age of the sample. For the $\mathrm{Al}$ center, an extremely thermally stable center, its lifetime is $7.4 \times 10^{9}$ years, but for the Ti center, it is $8.0 \times 10^{6}$ years at a granite sample from Japan [18]; [16]. The dose rate is obtained from the summation of the concentrations of radioactive substances in the sample (internal dose rate) and its surrounding environment (external dose rate). The doses of internal and external radioactivity must be determined individually due to the alter differences between them [19]. The annual dose of cosmic is about $0.3 \mathrm{mGy} / \mathrm{y}$ at sea level and reduces with depth beneath the ground, depending on the geographic latitude, the altitude and the thickness of the covering sediments [20]; [21]. As the external dose rate depends on the sample size, so if the outer $50 \mathrm{~mm}$ of the surface sample removed, the external alpha and beta dose will annihilate. Thus, it will consist of gamma-ray only. The gamma dose rate results from all sediment within a radius of about $30 \mathrm{~cm}$ around the sample, dose rate cannot normally be assumed from laboratory interpretations, but it has to be measured in situ with a portable, calibrated gamma detector or thermo luminescence dosimeters. Situ measurements have the benefit of involving the present-day water contents [22].

The internal dose rate parameter is mainly generated by estimated activity emitted from radioactive isotopes within the sample. For each sample, the radioactive nuclides concentration is measured by high-resolution gamma spectrometer then the dose rates determined to utilize the average $\mathrm{U}, \mathrm{Th}$, and $\mathrm{K}$ concentrations from the Guérin et al., 2011b [23] method. The residual dose correlated to aluminium hole free radical observed in the natural quartz by ESR after superior optical bleaching is formed by the occupancy of the deep Aluminium traps (DAT) at the crystal structure, that wasnot reset by the solar radiation, which is specific to an origin of quartz 
rock. As diamagnetic aluminium defects in the natural quartz lattice irradiated the number of DAT paramagnetic increases with irradiation process until all the aluminium holes have become paramagnetic [13]. The high dose of gamma irradiation impact on the natural milky quartz was investigated by using the X-ray powder diffraction (XRD), electron spin resonance (ESR), UV-visible spectroscopy (UV-vis), Fourier transform infrared (FTIR) spectrometer, also the surface microstructure given by scanning electron microscope (SEM), with elemental analysis measured by X-ray fluorescence (XRF) spectrometer and inductively coupled plasma optical emission (ICP-OES) spectrometer. In this work, the natural quartz samples were used asreceived and after gamma-irradiation at different radiation doses.

\section{Experimental}

Egyptian natural milky quartz crystals were used as-received from WadiAraba (WA), which is far $120 \mathrm{~km}$ from south of Suez, between Latitude $29^{\circ}$ $15^{\prime}-29^{\circ} 30^{\circ} \mathrm{N}$ and Longitude $32^{\circ} 14^{\prime}-32^{\circ} 24^{\prime}$ E, also WA Lies between the northern and southern Galala plateaus and in the east by the Gulf of Suez [24]. It is broad around $30 \mathrm{~km}$ and reaches to the middle of the Egyptian Eastern Desert limestone highland westward. WA has an $\mathrm{NE}-\mathrm{SW}$ wide, similar to the geographical Syrian Arc isocline formation path, which is one of the familiar features in northern Egypt [25]. The Galala plateaus are distinguished northward by Late Cretaceous [24,26].

The quartz samples were classified into four groups, separated using a diamond saw with cooling by water at optimal speed in slabs $(1.5 \mathrm{~cm}$ $\times 1.5 \mathrm{~cm} \times 6 \mathrm{~mm})$. The samples were irradiated at a ${ }^{60} \mathrm{Co}$ gamma irradiation cell (GC 220 Excel) (A product of MDS Nordion, Canada) for doses ranging from $100 \mathrm{kGy}$ to $1200 \mathrm{kGy}$, and the average dose rate was $1.67 \mathrm{kGy} / \mathrm{h}$. After gamma irradiation, all samples were ground into a fine powder using alumina motor to be suitable for analysis by different analytical techniques.

For the crystal structure of quartz samples, X-Ray diffraction patterns were made using a Shimadzu, XRD 6000 with $\mathrm{CuK} \alpha$ radiation $(1.5406 \AA), 40 \mathrm{kV}$, $30 \mathrm{~mA}$ at $0.80^{\circ} /$ step at $1 \mathrm{~min}$ and a standard scanning rang of $2 \Theta$ from $04^{\circ}$ to $90^{\circ}$ as shown in Figure (1). The crystallite size of milky quartz samples was estimated from X-ray diffraction data with handling the Scherrer formula. The JCPDS, 2000 file number 46-1045 was used as a reference in the XRD analyses. The elemental composition of the studied samples was obtained by X-ray fluorescence (XRF) spectrometer for major structure, the instrument utilizing JEOL, JSX3222, Japan. Today, it is applied as a nondestructive analytical manner and widely used in several industrial applications. In basis, it is usually tough to make quantification for elements lighter than sodium, without many improvements performed. In order to show tiny inclusions, the crushed milky quartz samples were examined under scanning electron microscope model JEOL, JSM-5600LV, with a working distance of $20 \mathrm{~mm}$, an accelerating voltage of $25 \mathrm{kV}$, with beam current as 40-100 nA and 10-2000× magnification. The electron microscope was equipped with a link energy dispersive spectrometer. The minor and trace elemental composition was performed using inductively coupled plasma optical emission spectrometer model Prodigy Prism High Dispersion (Teledyne Leeman ICP-OES USA).

Table (1): ICP-OES the measurement conditions

\begin{tabular}{c|c}
\hline ICP Spectrometer & $\begin{array}{c}\text { Leeman Prodigy } \\
\text { Prism ICP-OES } \\
\text { (USA) }\end{array}$ \\
\hline RF Power & $1.2 \mathrm{~kW}$ \\
\hline Coolant gas flow & $20 \mathrm{~L} / \mathrm{min}$ \\
\hline Auxiliary gas flow & $0.3 \mathrm{~L} / \mathrm{min}$ \\
\hline Nebulizer gas flow & $36 \mathrm{psi}$ \\
\hline Solution Uptake Rate & $1 \mathrm{~mL} / \mathrm{min}$ \\
\hline $\begin{array}{c}\text { Mg II/Mg I Ratio } \\
\text { (Robustness) }\end{array}$ & 6 \\
\hline Replicates & 3 \\
\hline Integration time & $10 \mathrm{sec}$ \\
\hline
\end{tabular}

The functional groups analysis was conducted at room temperature using Fourier transform infrared (FTIR) spectrometer, model Thermo Scientific Nicolet iS10, with the spectral range from 4000 $\mathrm{cm}^{-1}$ to $400 \mathrm{~cm}^{-1}$, with a resolution of $1 \mathrm{~cm}^{-1}$ and 128 scans. UV-vis spectra of the samples under the study, were created at the wavelengths ranging from 200 to $800 \mathrm{~nm}$, using a Uvicon 860 spectrophotometer (Kontron Co. Ltd., Switzerland), samples were measured as suspended solution with empty tube as reference for the first sample and then the first sample reference for the other samples, also the thickness 
of the sample was taken as the path length of holder tube and the mode of measure was absorbance (A). During the measurements, the samples were held in a plastic holder after creating a suspended solution with deionized water, and an empty holder kept as a reference.

The free radicals signals were recorded at room temperature using a Continuous Wave ESR spectrometer (model: X-band Bruker EMX spectrometer, a product of Bruker, Germany) with a rectangular cavity of ER 4102, after the irradiation process. The operating parameters applied during the ESR experiment were: microwave power, $1.01 \mathrm{~mW}$; microwave frequency, $9.65 \mathrm{GHz}$; modulation amplitude, 6 Gauss; modulation frequency, $100.00 \mathrm{kHz}$; resolution, 1024 points; sweep width, 900 Gauss; time constant, $81.92 \mathrm{~ms}$; conversion time, 20.48 ms and sweep time, $20.97 \mathrm{~s}$. An average weight around $0.249 \mathrm{~g}$ of each sample was loaded in a fused quartz tube of $4 \mathrm{~mm}$ internal diameter, which was placed in the ESR cavity. A high purity vertical (HPGe, p-type) detector was applied for evaluating the $\gamma$-ray spectrum of the milky quartz sample. The energy resolution of the detector was $1.95 \mathrm{keV}$ at the $1332 \mathrm{keV} \gamma$-ray line of ${ }^{60} \mathrm{Co}$ source with a relative efficiency of $25 \%$. The detector was joined to reliable Genie-2000 software from Canberra for data analysis with numerous measurement functions.

\section{Results and Discussion}

The elemental structure of the natural milky quartz specimens, which were handled are presented at Tables (2 and 3) from which the high purity of the Egyptian natural quartz could be observed as it holds $99.5 \%$ of silicon oxide $\left(\mathrm{SiO}_{2}\right)$ with impurities (e.g. Al, $\mathrm{Fe}, \mathrm{Ca}$, and unusual traces reach to, $0.03 \%$ ). It was also observed that milky white samples listed have high concentrations of aluminum, calcium, iron, and potassium usually above $450 \mathrm{ppm}, 220 \mathrm{ppm}, 350 \mathrm{ppm}$ and $40 \mathrm{ppm}$, respectively. In addition, it contains significant concentrations of sodium, barium and magnesium reach to $40 \mathrm{ppm}, 50 \mathrm{ppm}$ and $30 \mathrm{ppm}$, respectively. Therefore, it is essentially used for different purposes and applications. All results are of a relative standard error (RSD). It is noticed that the XRF results for $1 \%$ just indicated element existence, therefor, a trace element analysis was conducted by ICP-OES to evaluate these trace elements, as shown Table (2) for major ratios that well confirmed $\mathrm{SiO} 2$ only and trace elements (Table 3).

Figure (1) presents the XRD pattern of the natural quartz sample as-received, that designated that the structure of silicon dioxide $\left(\mathrm{SiO}_{2}\right)$, resembles the standard pattern number 46-1045 (JCPDS, 2000) given by ICDD, (2001) [27], also the XRD patterns of the quartz samples after gamma irradiation are presented in Figure (1). The irradiated sample of the natural quartz has XRD patterns similar to that of the as-received one. It is specified that the natural milky quartz structure did not significantly change after subjected to high doses of gamma rays. The lattice parameters c/a ratios did not approximately changewith different gamma irradiation doses, they were around 1.1.

Figure (3) shows the microstructure of the natural milky quartz examined by Scanning Electron Microscope (SEM) that proved the presence of several forms of solid inclusions dispersed in the pattern at an arbitrary manner; also it could discern the fluid formations, with both irregular shape and dimensions. The natural milky quartz usually holds abundant of fluid bubbles consist of gas phase (e.g., $\mathrm{CO} 2$ ) and liquid phase (e.g., $\mathrm{OH}$ group) associated with enormous number and small size, so it is difficult for complete separation to occur. It is noted that at FTIR spectrum, the $\mathrm{CO}_{2}$ has a specific absorption around $1760 \mathrm{~cm}-1$ and indicate free $\mathrm{HOH}$ appear as a broad peak around $3400 \mathrm{~cm}-$ 1 see figure 4 .

The normalized FTIR spectra recorded at room temperature are shown in Figure (4). Measurements were performed with dilution of the sample in KBr. In literature, the wavenumbers range from $3000 \mathrm{~cm}^{-1}$ to $3600 \mathrm{~cm}^{-1}$ typically implying $\mathrm{OH}$ interactionssignificant in the analysis of the color growing potential in the quartz [10]; [28]. More in-depth studies are needed for the potentially confused bands within determination of noise made in order to decide some of those bands, such as vibrational forms of the charge compensators such as $\mathrm{Li}, \mathrm{H}, \mathrm{Na}, \mathrm{K},\left[\mathrm{AlSiO}_{4}\right]^{-}$, and

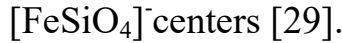


Table (2): Major elemental composition interpretation of the natural milky quartz sample

\begin{tabular}{c|c|c}
\hline Instrument & \multicolumn{2}{|c}{ XRF (major elements) } \\
\hline Oxides & Natural Milky Quartz (\%) & RSD \\
\hline $\mathrm{SiO}_{2}$ & 99.54 & $\pm \mathbf{0 . 6 0 7 5}$ \\
$\mathrm{CaO}$ & 0.08 & \pm 0.2409 \\
$\mathrm{Fe}_{2} \mathrm{O}_{3}$ & 0.12 & \pm 0.0422 \\
$\mathrm{Al}_{2} \mathrm{O}_{3}$ & 0.23 & \pm 0.1938 \\
\hline Other & 0.03 & \\
\hline Total & 100 & \\
\hline
\end{tabular}

Table (3): The trace elements analysis of the natural milky quartz sample ICP-OES (trace elements)

\begin{tabular}{|c|c|c|c|c|}
\hline Elements & $\begin{array}{c}\text { Wavelengths } \\
\text { (nm) }\end{array}$ & $\begin{array}{c}\text { Average concentration } \\
(\mathrm{ppm})\end{array}$ & RSD & Emission Type \\
\hline Al & 396.152 & $\mathbf{4 7 9 . 4}$ & \pm 1.1716 & atomic \\
\hline $\mathbf{F e}$ & 259.94 & 370.8 & $\pm \mathbf{0 . 4 2}$ & ionic \\
\hline $\mathbf{C a}$ & 317.933 & 241.48 & \pm 0.51 & ionic \\
\hline $\mathbf{K}$ & 766.491 & 39.91 & \pm 1.2 & atomic \\
\hline $\mathbf{N a}$ & 589.592 & 42.56 & \pm 0.99 & atomic \\
\hline $\mathbf{B a}$ & 455.403 & 55.87 & \pm 1.1 & ionic \\
\hline Mg & 279.553 & 30.37 & \pm 0.28 & ionic \\
\hline $\mathrm{Cr}$ & 267.716 & 18.15 & \pm 0.42 & ionic \\
\hline $\mathbf{Z n}$ & 206.2 & 15.19 & \pm 0.44 & ionic \\
\hline Mn & 257.61 & 12.04 & $\pm \mathbf{0 . 4 5}$ & ionic \\
\hline $\mathbf{T i}$ & 334.941 & 10.33 & $\pm \mathbf{0 . 7 8}$ & ionic \\
\hline $\mathbf{N i}$ & 232.003 & 8.27 & \pm 1.7 & atomic \\
\hline $\mathrm{Cu}$ & 324.754 & 1.93 & $\pm \mathbf{0 . 7 8}$ & atomic \\
\hline $\mathbf{L i}$ & 670.784 & 1.6 & $\pm \mathbf{0 . 5 5}$ & atomic \\
\hline Co & 228.615 & 0.494 & \pm 1 & ionic \\
\hline La & 333.749 & 0.3174 & \pm 3.64 & ionic \\
\hline $\mathrm{Ce}$ & 413.765 & 0.7314 & $\pm \mathbf{3 . 2 8}$ & ionic \\
\hline Er & 337.271 & 16.18 & \pm 0.46 & ionic \\
\hline $\mathbf{P}$ & 213.618 & 3.3 & $\pm \mathbf{0 . 7 5}$ & atomic \\
\hline Ga & 417.204 & 2.2 & \pm 1.55 & atomic \\
\hline $\mathrm{Sr}$ & 407.771 & 1.6 & $\pm \mathbf{3 . 2 3}$ & ionic \\
\hline
\end{tabular}

(a) 
Table (4): Lattice parameters of the unit cell and crystal size of quartz samples as received (0 kGy) and irradiated $(400,800$ and $1200 \mathrm{kGy})$

\begin{tabular}{c|c|c|c|c}
\hline Sample & $\mathbf{a}(\AA)$ & $\mathrm{c}(\AA)$ & $\mathbf{c} / \mathbf{a}$ & $\begin{array}{c}\text { Average } \\
\text { particle size } \\
(\mathbf{n m})\end{array}$ \\
\hline $0 \mathrm{kGy}$ & 4.938 & 5.417 & 1.097 & 55.52 \\
\hline $400 \mathrm{kGy}$ & 4.875 & 5.380 & 1.104 & 47.71 \\
\hline $800 \mathrm{kGy}$ & 4.828 & 5.369 & 1.112 & 36.04 \\
\hline $1200 \mathrm{kGy}$ & 4.929 & 5.412 & 1.098 & 62.59 \\
\hline
\end{tabular}

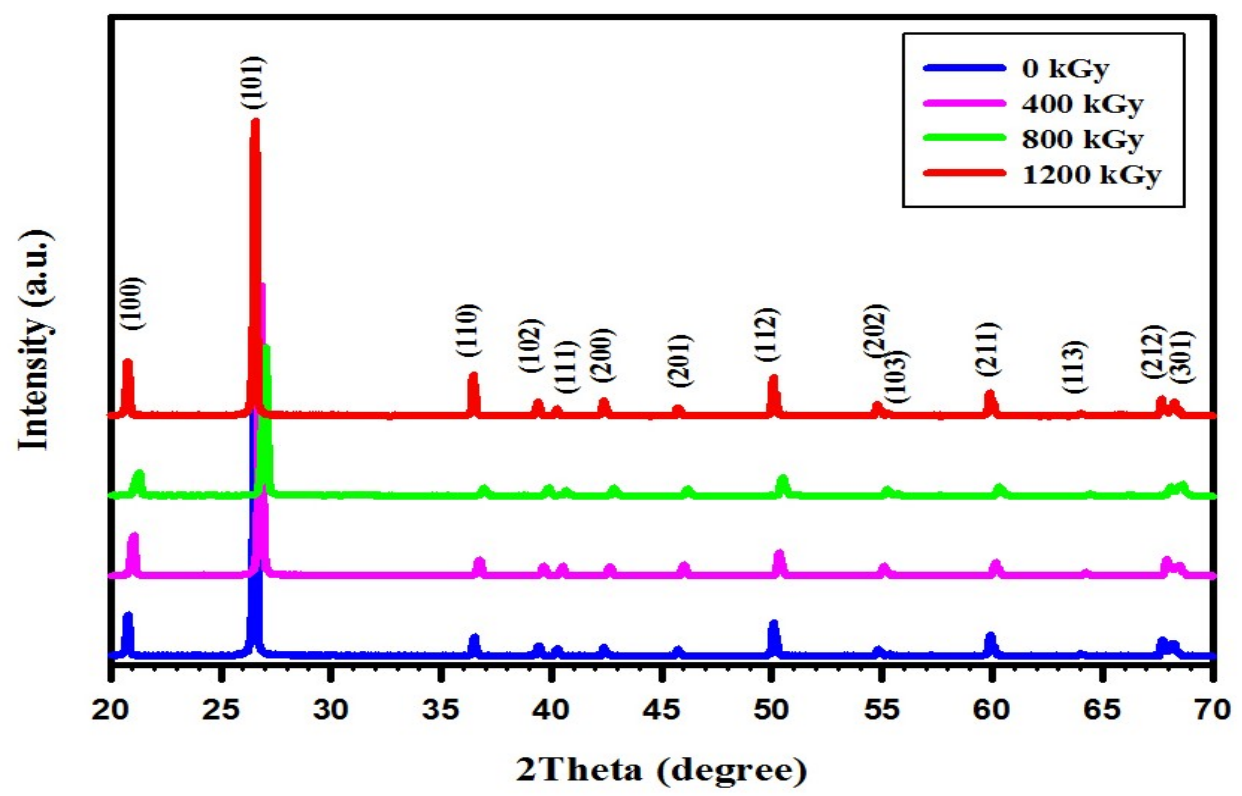

Fig. (1): XRD patterns for the samples as received and after gamma irradiation $(400,800,1200 \mathrm{kGy})$

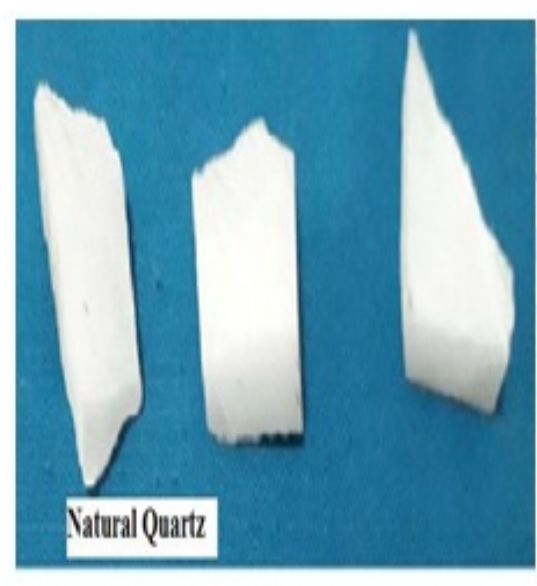

(a)

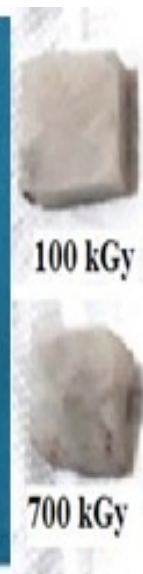

$700 \mathrm{kGy}$

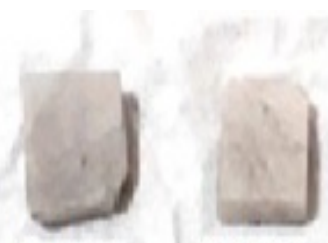

$200 \mathrm{kGy} \quad 300 \mathrm{kGy}$

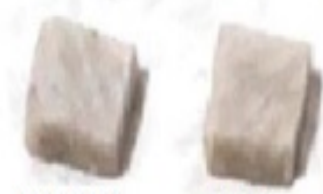

$800 \mathrm{kGy}$

$900 \mathrm{kGy}$
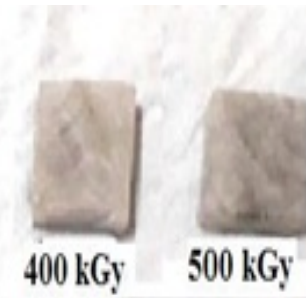

$600 \mathrm{kGy}$

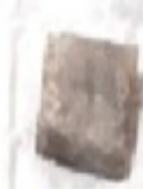

$1000 \mathrm{kGy}$

$1100 \mathrm{kGy} \quad 1200 \mathrm{kGy}$

(b)

Fig. (2): Photograph of studied quartz crystals, (a) as received and (b) after gamma irradiation 


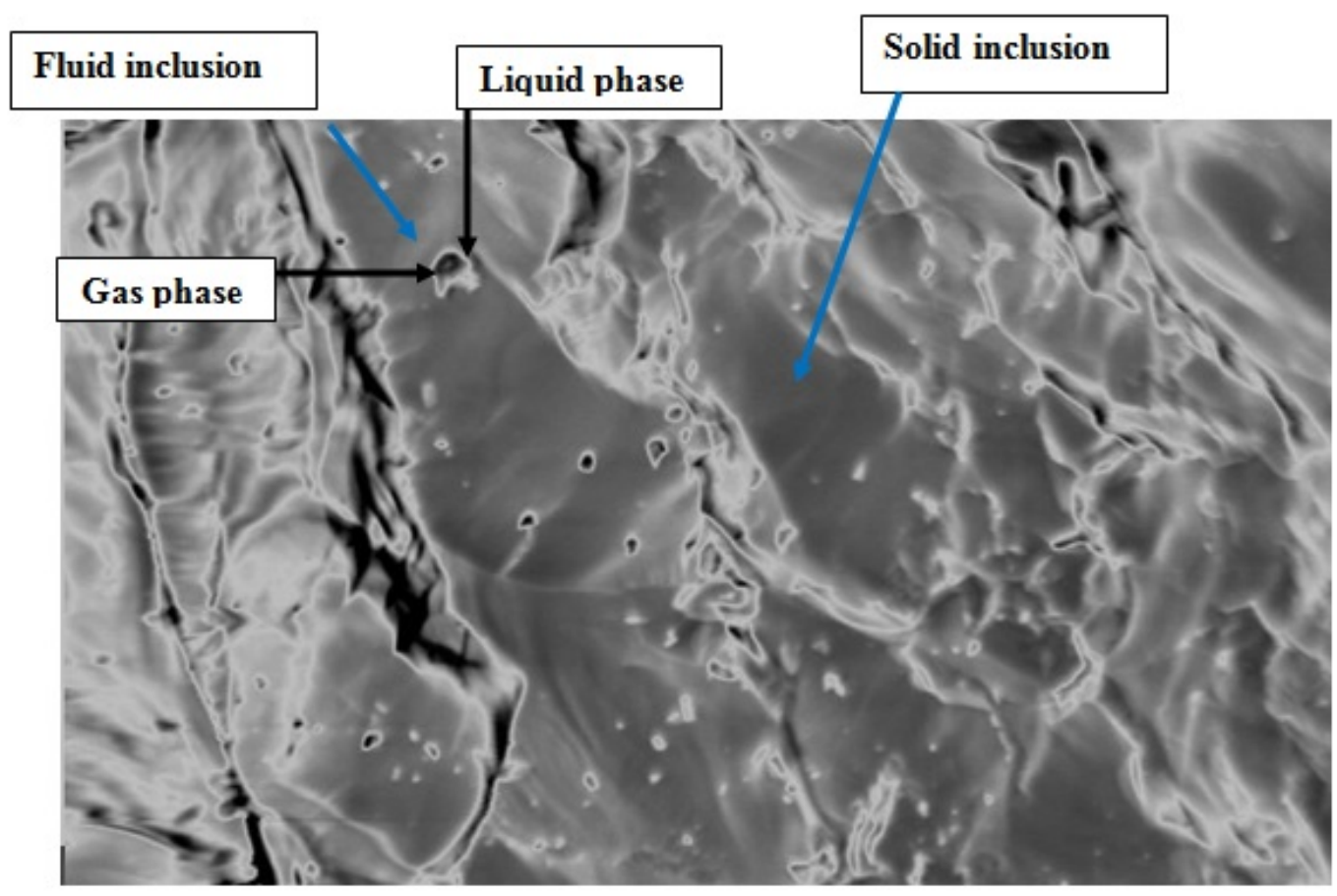

Fig. (3): Microstructure of natural milky quartz as received

Table (5): Dos rate (D) for quartz sample due to the radioactive elements (U, Th, K)

\begin{tabular}{ccccc}
\hline $\begin{array}{c}\mathrm{U}-238 \\
(\mathrm{~Bq} / \mathrm{kg})\end{array}$ & $\mathrm{Th}-232(\mathrm{~Bq} / \mathrm{kg})$ & $\begin{array}{c}\mathrm{K}-40 \\
(\mathrm{~Bq} / \mathrm{kg})\end{array}$ & $\begin{array}{c}\text { Cosmic rays }(\mathrm{mSv} / \mathrm{a}) \\
{[20] ;[21]}\end{array}$ & Dose rate D (mSv/a) \\
\hline 14.41 & 9.579 & 17.43 & 0.03 & 0.05 \\
\hline
\end{tabular}

The fingerprint of infrared bands related to quartz crystals is in the region of $1200-400 \mathrm{~cm}^{-}$ ${ }^{1}[30] ;[31]$. In the reviewed samples, the $\mathrm{SiO}_{4}$ tetrahedra manifests $\mathrm{Si}-\mathrm{O}$ asymmetrical stretching fluctuation (v3) at $1080 \mathrm{~cm}^{-1}, \mathrm{Si}-\mathrm{O}$ symmetrical stretching fluctuation (v1) at $785 \mathrm{~cm}^{-}$ 1, Si-O symmetrical twisting fluctuation (v2) at $693 \mathrm{~cm}^{-1}$, and $\mathrm{Si}-\mathrm{O}$ asymmetrical twisting fluctuation (v4) at $451 \mathrm{~cm}^{-1}$ as shown in Figure 4.

The peak at $693 \mathrm{~cm}^{-1}$ arises due to the octahedral position arrangement which is unique for crystalline materials and the tetrahedraltetrahedral ion fluctuation influences the band at $785 \mathrm{~cm}^{-1}$ in silicates; the tetrahedral dimension is usually recognized to be lightly altered by pressure and temperature [31,32].

The tetrahedral locality arrangement is powerful to that of octahedral locality arrangement. Therefore, for any structural modification, the destruction transpires first in octahedral locality arrangement then in tetrahedral Arab J. Nucl. Sci. \&Applic. Vol. 53, No.3 (2020) locality arrangement. The intensity of the bands due to the fluctuations of these two arrangements will produce a direct erudition on the crystallinity and crystal growth [31].

The Authors concentrated on these specific peaks at $2890 \mathrm{~cm}^{-1}$ and $2977 \mathrm{~cm}^{-1}$ of each sample to examine the $\mathrm{Si}-\mathrm{O}$ structural bond [8]. The variation of peak areas in the tetrahedral and octahedral locality arrangement designates the induced impression of trace elements or oxides joined to the quartz crystal through gamma-ray irradiation. It will result in a color change of the quartz crystals. The milky white color of quartz crystals is due to the proximity of traces of $\mathrm{Ca}$, the presence of $\mathrm{Al}$ impurities is responsible for displaying the grayish to black color, if any existence of red and green color is noted, it is because of $\mathrm{Fe}, \mathrm{Ti}$ and $\mathrm{Cr}$ trace defects respectively [29].

The FTIR spectra analysis of the natural milky quartz is shown in Figure (4). The bands at $3338 \mathrm{~cm}^{-1}, 3465 \mathrm{~cm}^{-1}$ and $3444 \mathrm{~cm}^{-1}$ are linked to 
$[\mathrm{Al}-\mathrm{OH} / \mathrm{Li}]^{+}, \quad[\mathrm{Al}-\mathrm{OH} / \mathrm{Na}]^{+}$and $\quad[\mathrm{Al}-\mathrm{OH}]^{+}$and represents a vital role in the color center creation. It is noticeable in the specimens that develop colors of practical value after irradiation. As there is no limitation on the fragment thickness that the total absorbance values are insignificant. The bands at $2890 \mathrm{~cm}^{-1}$ to $2977 \mathrm{~cm}^{-1}$ are correlated to the Si-O bond, and not influenced by the irradiation and are already present in all specimens. The infrared spectrum of all milky white samples of the natural alpha quartz displays bands at 2977, 2890, 1080, 785, 693 and $451 \mathrm{~cm}^{-1}$, also four slight bands were perceived at 1300 , 2890, 2977 and $3685 \mathrm{~cm}^{-1}$. The samples that do not develop colors after irradiation show bands at 3202 and $3304 \mathrm{~cm}^{-1}$ (meanings of the $\mathrm{Si}-\mathrm{O}$ bond still exist, not detected here) [31].

The samples that grows grayish to black after irradiation exhibit extra three bands at 3338, 3444 , and $3465 \mathrm{~cm}^{-1}$. This last band explains the change of the colors from white to grayish after irradiation. The strength of these colors is proportional to the strength of this band. The samples that became grayish green after irradiation at very high radiation doses, in expanding to the former bands, they develop a couple of bands at 3685 and $3739 \mathrm{~cm}^{-1}$. The characters at $3685 \mathrm{~cm}^{-1}$ are linked to $\left[\mathrm{Al}_{\mathrm{Si}} \mathrm{O}_{4} / \mathrm{H}_{\mathrm{i}}^{+}\right]^{0}$, where $\mathrm{Al}_{\mathrm{Si}}$ designs an $\mathrm{Al}$ ion at $\mathrm{Si}$ position, change $\mathrm{Al}$ is a charge adjusted by $\mathrm{H}^{+}$at a silicon position.

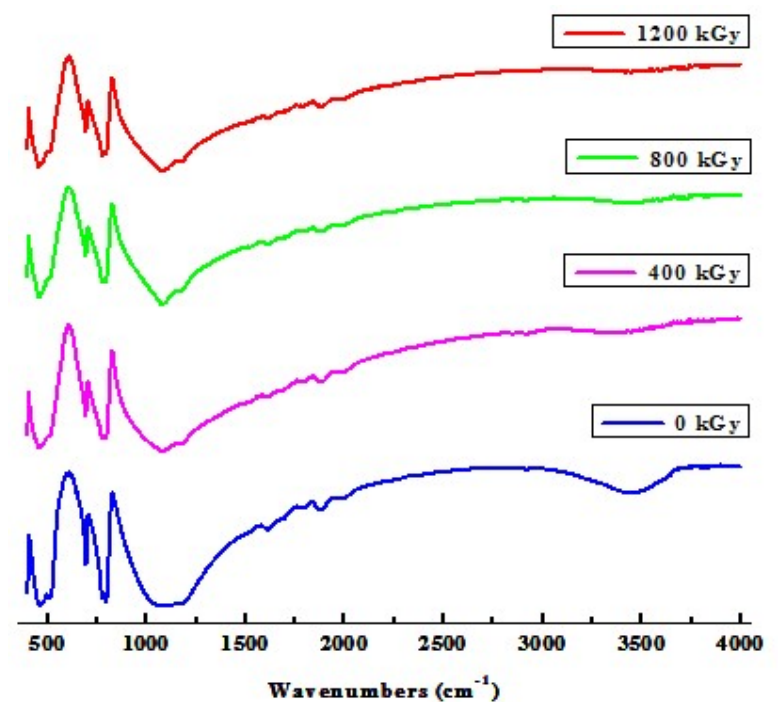

Fig. (4): FTIR spectra of the milky quartz crystal samples in the finger print region

Figure (5) displays the UV-vis spectra for the natural milky quartz. From the spectra, it could noticed that the absorption bands were around 320 and $360 \mathrm{~nm}$ for the irradiated andas-received samples and they increase with increasing the radiation dose. In addition, the absorption band at $360 \mathrm{~nm}$ is in near ultraviolet (NUV) region, the absorbance spectrum of the milky quartz samples implies a shift in spectra towards the visible region (lower wavelengths) as shown in Figure (5). Because of gamma irradiation, the progressive shift in the absorption threshold may be attributed to breakage of the bonds, so the volatile species could be released, chain scission, cross-linking, free radical production, defects, and new bonds creation [33]; [34]. The mixture of these bands provides a deep milky white look raw material. These absorbance peaks at $320 \mathrm{~nm}$ and $360 \mathrm{~nm}$ may be related to the unusual oxidized high ratio of specific impurity ions by irradiation, such as $\mathrm{Al}$ (IV)/M+. The UV-vis spectrum of the irradiated samples which exhibited an approximately uniform absorption across the visible region. The dark grayish-black coloration of irradiated milky quartz is due to the loss of transmittance of radiation in the visible region, but absorbance was at or near the UV region[35].

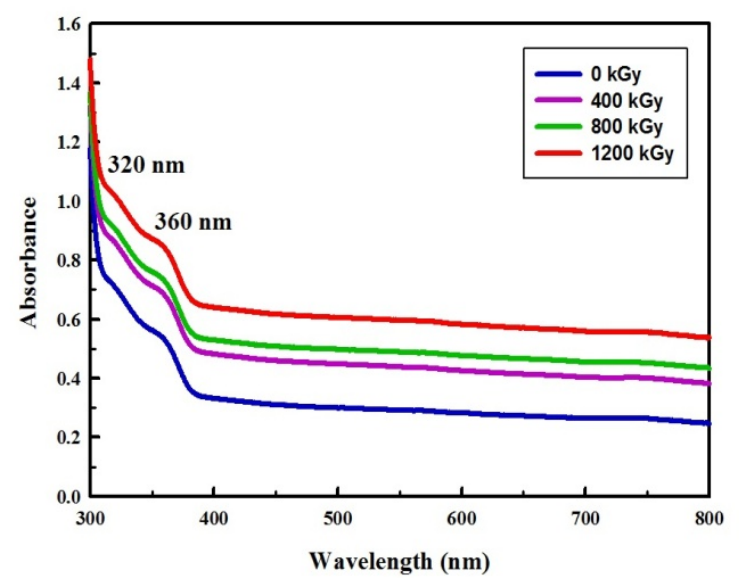

Fig. (5): UV-vis absorption spectra of the natural milky quartz as received and after irradiation at doses $(400 \mathrm{kGy}, 800 \mathrm{kGy}$ and $1200 \mathrm{kGy})$

Tauc equation gives the absorption coefficient $(\alpha)$ that is relevant to the optical band gap and the frequency necessity [36];

$$
\alpha h v=C\left(h v-E_{g}\right)^{n}
$$

Where $\mathrm{C}$ is a constant, $\mathrm{h}$ is Planck's constant; $v$ is the radiation frequency, $\mathrm{E}_{\mathrm{g}}$ is the optical band gap and the electronic transition characterized by $n$ index. To estimate the direct optical band gap from absorption analysis, we should extrapolate the 
straight line part of the curves $(\alpha h v)^{2}\left(\mathrm{~cm}^{-1} \cdot \mathrm{eV}\right)^{2}$ versus (hv) as presented in Figure (6) for the asreceived and gamma irradiated samples. The reduction of the optical band gap with increasing the dose is probably due to defects created in the natural milky quartz material, which was associated with its color change from white to grayish. The direct opticalband gap for milky quartz samples are slightly varying around 4 to 3.9 $\mathrm{eV}$.

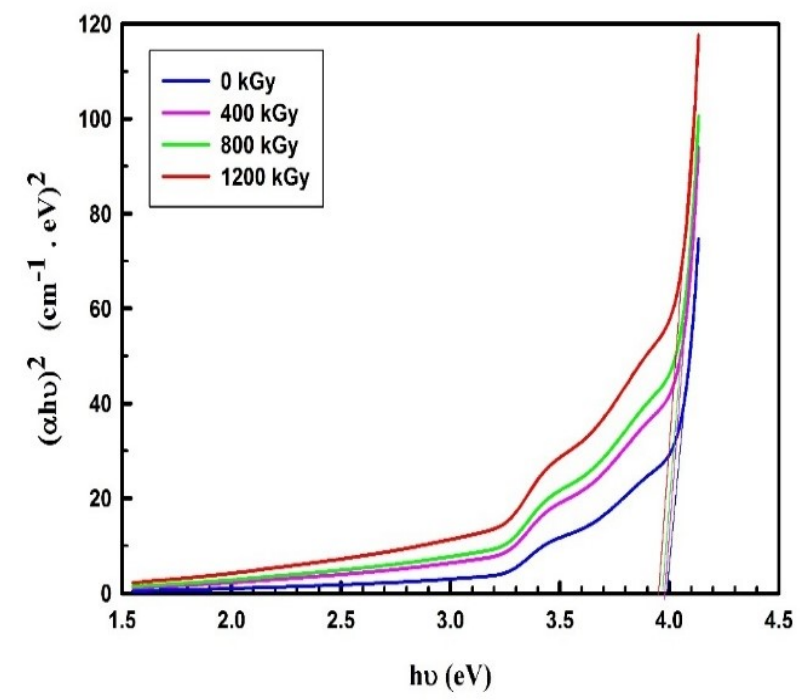

Fig. (6): The relation between $(\alpha h v)^{2}$ and the photon energy hv (eV) for natural milky quartz samples irradiated at different radiation doses

on the other hand, studies presented by Malik et al., [37]; Gabora et al., [38] stated that Al regularly exists in quartz, which provides $\left[\mathrm{AlO}_{4} / \mathrm{M}^{+}\right]^{0}$ (where $\mathrm{M}^{+}$designates to $\mathrm{H}^{+}$or $\mathrm{Li}^{+}$, Naor alkali metal). The separation of $\left[\mathrm{AlO}_{4} / \mathrm{M}^{+}\right]^{0}$ appears during the irradiation process into $\left[\mathrm{AlO}_{4} / \mathrm{H}^{+}\right] 0$ and $\left[\mathrm{AlO}_{4}\right]^{0}$, and its strength relatively depends on the dose rate $[39,40]$, recently more studies frequently use this signal in ESR sediments age dating [41,42].

Figure (7) presents ESR spectra of the milky quartz sample. Most of the free radical lines mentioned in these spectra can correlate to typical Al-hole signals. Al hole signals for the natural milky quartz samples are utilized at $\mathrm{g}=2.015$, $\mathrm{g}=1.96$, but Al-hole $\mathrm{g}$ value is typically generated at the $\mathrm{g}=2.018$ to $\mathrm{g}=1.993$ that established by Toyoda et al., [43,44].

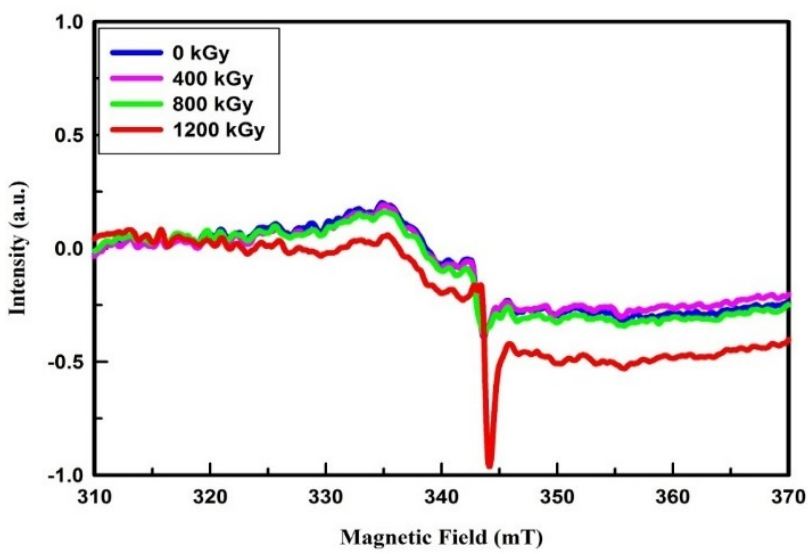

Fig. (7): ESR spectra of milky quartz.

The ESR intensity of the Al hole center increased with increasing the dose at the magnetic field range of 340-350 $\mathrm{mT}$. In general, as doses increase, also the signal intensity increased with a little change in the width of the line that is attached to destroy of the $\mathrm{Si}-\mathrm{O}$ bonds in the lattice at high doses, which has g value equal to 2.00 . Toyoda et al., [43] summarized the overlapping of $E_{1}$, peroxy, and $\mathrm{OHC}$ center, with the $\mathrm{Al}$ hole center as publicized in outcomes. Therefor, Al hole center was done a high-intensity signal at $5 \mathrm{~mW}$, with a g-value of 2.01509, which suggested a good face in ESR dating work. The natural DRC of the Al hole center gave an unexpected quick saturation, with a particular saturation dose value above 900 $\mathrm{kGy}$ for the $\mathrm{Al}$ hole center, when fitted with an exponential function, that statistically extrapolation with $2^{\text {nd }}$ order polynomial function as illustrated in Figure (8). An accurate statistical analysis is needs to 12 points at least on the doseresponse curve of the irradiated quartz samples. Intensity increases with the dose, thus extrapolation to the $\mathrm{x}$-axis gives the accumulated dose (AD). The predicted (AD) was estimated by extrapolation the dose-response curve till intersect the dose axis then the age of the sample (T) is calculated by dividing the accumulated dose (AD) by the dose rate (D) with approximately $\pm 10 \%$ uncertainty in the age of the different samples from different locations. It is noted that one sample will give a fake result. [45]; [22]; [15]. 


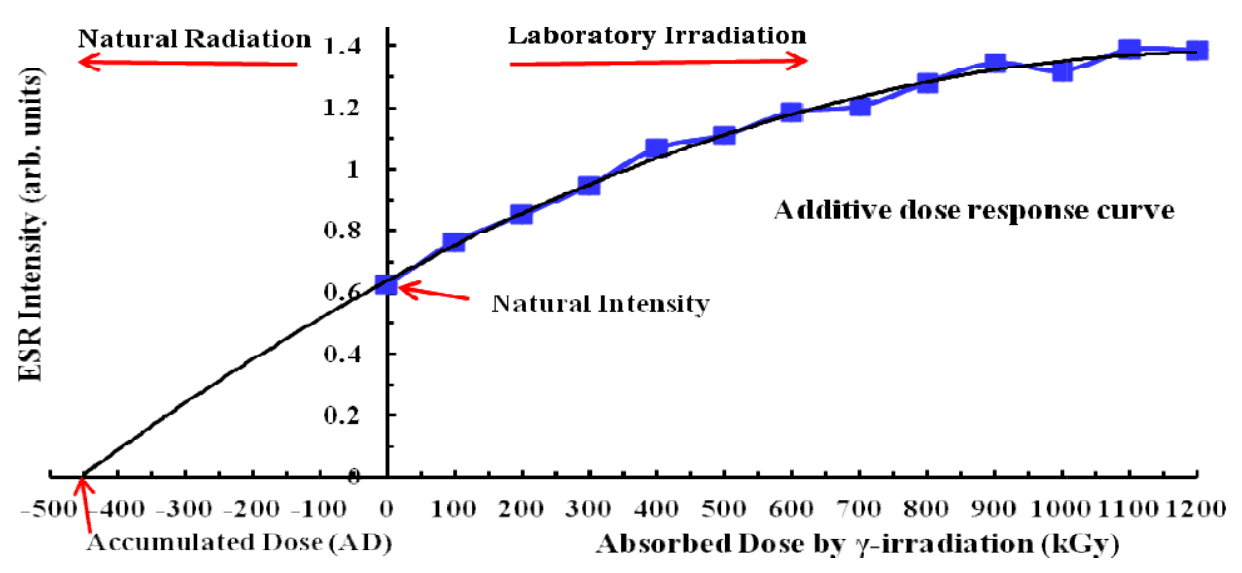

Fig. (8): The ESR intensity of the Al hole center distinct with $\gamma$ irradiation doses in range from 0 to $1200 \mathrm{kGy}$.

The essential part of ESR dating method is measuring the $\mathrm{AD}$, besides the dose rate (D) computed from the natural radioactivity by measuring concentrations of the natural radionuclides (essentially $\mathrm{Th}, \mathrm{U}$, and $\mathrm{K}$ ) in the sample and cosmic ray. All Activity of 238-U, 232-Th and 40-K, also dose rates, ages, and expected doses are summarized in Table (5), which just explain the ESR dating method steps not for calculating the accurate age. The age $(\mathrm{T})$ of the ESR signal $(\mathrm{g}=2.015)$ for the milky quartz was obtained by dividing the accumulated doses (AD) by the dose rate (D).

The dose rate of the sample can be determined using two approaches:

(1)Tsakalos et al., [46] introduced a free software Dose-Rate calculator (DRC) program code for dose-rate and age calculation, also the Dose Rate and Age Calculator (DRAC) program code was presented by Durcan et al., [47-49].

(2)The absorbed dose rate $\left(\mathrm{D} ; \mathrm{nGyh}^{-1}\right)$ was calculated using the formula of Papaefthymiou and Psichoudaki et al., [50] fromthe radionuclides ${ }^{238} \mathrm{U},{ }^{232} \mathrm{Th}$ and ${ }^{40} \mathrm{~K}$ activities.

$$
\begin{aligned}
\mathrm{D}\left(\mathrm{nGyh}^{-1}\right)= & 0.462 \mathrm{C}_{\mathrm{u}}+0.604 \mathrm{C}_{\mathrm{Th}} \\
& +0.042 \mathrm{C}_{\mathrm{K}}
\end{aligned}
$$

Where, $\left(\mathrm{C}_{\mathrm{U}}, \mathrm{C}_{\mathrm{Th}}\right.$ and $\left.\mathrm{C}_{\mathrm{K}}\right)$ are the ${ }^{238} \mathrm{U},{ }^{232} \mathrm{Th}$ and ${ }^{40} \mathrm{~K}$ are activity concentrations $(\mathrm{Bq} / \mathrm{kg})$ respectively. The activity concentrations range of 40-K, 238-U and 232-Th will have differences associated with the rock class differences in the area under the study. The variations are the outcomes of the geochemical composition and origin of rock types in a specific region [51].

\section{CONCLUSIONS}

The natural milky quartz specimens from WA, Egypt contain a well-defined Al hole center ESR signal which increases with increasing the $\gamma$ irradiation dose up to $1200 \mathrm{kGy}$, particularly at a g-value of 2.015 peak. Also, it is confirmed by absorption peak at the UV- vis spectrum at $360 \mathrm{~nm}$ characteristic for $\mathrm{Al}$ that is called near ultraviolet, also the FTIR bands were observed at a range from 3000-3600 wavenumbers $\mathrm{cm}^{-1}$, especially at 3433 and $3483 \mathrm{~cm}^{-1}$ for $[\mathrm{Al}-\mathrm{OH} / \mathrm{Na}]^{+}$and $[\mathrm{Al}-\mathrm{OH} / \mathrm{Li}]^{+}$, respectively that indicates color change to grayish or black after irradiation. The vibration that produces the $3685 \mathrm{~cm}^{-1}$ band can be an active form in FTIR spectroscopy, but in the natural milky quartz samples need further studies. The peak height of the Al hole center ESR signal in additive dose response curve was increased as a polynomial function over gamma-ray doses. Free radical at ESR spectra indicate a significant application of ESR dating technique for $\mathrm{Al}$ hole center in themilky quartz, but it may be confusing in some cases.

\section{High Lights:}

- Egyptian natural quartz is of high purity with a lot of valuable applications.

- Irradiated quartz is sensitive to very high gamma-radiation doses.

- ESR dating of Al hole center in natural quartz.

- Two approaches are set for calculation of the dose rates for the environmental and archaeological samples. 


\section{References}

1. Insiripong, S., Kedkaew, C., Thamaphat, K., Chantima, N., Limsuwan, P., Kaewkhao, J., 2012. Irradiation effect on natural quartz from Zambia. Procedia Engineering. 32, $83-89$.

2. Melanie Bartz, Lee J. Arnold, Nigel A. Spooner, Martina Demuro, IsidoroCampaña, Gilles Rixhon, Helmut Brückner\& Mathieu Duval, 2019. First experimental evaluation of the alpha efficiency in coarsegrained quartz for ESR dating purposes: implications for dose rate evaluation, Scientific Reports, 9:19769, https://doi.org/10.1038/s41598-019-54688 $-9$.

3. Bahadur, H., Tissoux, H., TeruoUsami, T., Toyoda, S., 2008. Radiation effects in natural quartz crystals. J Mater Sci: Mater Electron, 19:709-713.

4. Botis, S., 2005. Electron paramagnetic resonance spectroscopy study of radiation damage induced cathode luminescence quartz, Athabasca basin. University of Saskatchewan, 114 Science Place, Saskatoon, Saskatchewan, S7N 5E2 CANADA.

5. MacKeever, S.W.S., 2006. Thermoluminescence in quartz and silica. Radiat. Protect. Dosim. 119, 168-171.

6. Sawakuchi, G.O., Okuno, E., 2004. Effects of high gamma ray doses in quartz. Nucl. Instrum. Methods Phys. Res. Sect. B 218, 217-221.

7. Nassau, K., 1984. Gemstone Enhancement,first ed. Butterworths, Boston.

8. Lameiras, F.S., 2012. The relation of FTIR signature of natural colorless quartz to color development after irradiation and heating. In: Morozhenko, V. (Ed.), Infrared Radiation. InTech, Rijeka, pp. 4156.

9. Hantehzadeh, M.R., Han, C.S., Halliburton, L.E., 1990. Radiation-induced mobility of interstitial alkali ions in irondoped quartz. J. Phys. Chem. Solids 51, 425-429.

10. Nunes, E.H.M., Lameiras, F.S., Manual, H., Vasconcelos, W.L., 2013. Spectroscopic study of natural quartz samples. Rad. Phys. Chem. 90, 79-8680.
11. AnasBoussaa S., Kheloufi A., BoutarekZaourar N., 2017. Characterization of impurities present on Tihimatine (Hoggar) Quartz, Algeria. Journal of African Earth Sciences, doi: 10.1016/j.jafrearsci.2017.09.001.

12. Bahain, J.J., Laurent, M., Falguères, C., Voinchet, P., Farkh, S., Tissoux, H., 2002. Electron paramagnetic resonance (EPR) dating of Pleistocene fluvial formations and associated archaeological or palaeontological deposits. Quaternary 13, 91-103.

13. Tissoux, H., Voinchet, P., Lacquement, F., Prognon, F., Moreno, D., Falguères, C., Bahain, J., Toyoda, S., 2012. Investigation on non-optically bleachable components of ESR aluminium signal in quartz. Rad. Meas., 47, 894-899.

14. Rink, W.J., Bartoll, J., Schwarcz, H.P., Shane, P.,Bar-Yosef, O., 2007. Testing the reliability of ESR dating of optically exposed buried quartz sediments. Radiat. Meas. 42, 1618-1626.

15. Duval, M., 2012. Dose response curve of the ESR signal of the aluminiumcentre in quartz grains extracted from sediment. Ancient TL 30, 41-50.

16. Tsukamoto, S., Long, H., Richter, M., Li, Y., King, G.E., He, Z., Yang, L., Zhang, J., 2018. Quartz natural and laboratory ESR dose response curves: A first attempt from Chinese loess. Rad. Meas.

17. Aitken, M. J., 1985. Thermoluminescence dating. Academic Press, London.

18. Toyoda, S., Ikeya, M. 1991. ESR dating of quartz and plagioclase from volcanic ashes using E'1, Al and Ti centres. Nuclear Tracks and Radiat. Meas. 18, 179-184.

19. Grun, R., S tringer C. B., 1991. Electron Spin Resonance Dating and The Evolution of Modern Humans. Archaeometry 33, 2, 153-199.

20. Prescott JR and Hutton JT (1988) Cosmic ray and gamma ray dosimetry for TL and ESR.Nuclear Tracks and Radiation Measurement14: 223-227.

21. Ikeya, M., 1993. New Applications of Electron Spin Resonance: Dating, Dosimetry and Microscopy. World Scientific Publ. Co., Singapore, 500p. 
22. Grun, R., 2008. Electron Spin resonance Dating. The Australian National University, Canberra, ACT, Australia.

23. Guérin, G., 2011b. Numerical modeling and simulations of dosimetric effects in quaternary sediments: application to luminescence dating methods. Doctoral thesis in Physics of archaeomaterials, Bordeaux, Michel de Montaigne University Bordeaux 3, 242p.

24. Bucur, I. I., Nagm, E., Wilmsen, M., 2010. Upper Cenomanian-Lower Turonian (Cretaceous) calcareous algae from the Eastern Desert of Egypt. StudiaUniversitatis Babes-Bolyai, Geologia 55, 29-36.

25. Said, R. 1990, The geology of Egypt. Balkema, Rotterdam, $721 \mathrm{p}$.

26. Kuss, J., Scheibner, C., Gietl, R. 2000, Carbonate platform to basin transition along an Upper Cretaceous to Lower Tertiary Syrian arc uplift, Galala plateaus, Eastern Desert, Egypt. GeoArabia, 5 (3): 405-424.

27. ICDD, (2001) Powder Diffraction File. International Center for Diffraction Data. Newtown, Square, PA, USA

28. Nunes, E.H.M., Melo, V.A.R., Lameiras, F.S., Liz, O., Pinheiro, A., Machado, G., Vasconcelos, W.L., 2009. Determination of the potential for extrinsic color development in natural colorless quartz. Am. Mineral. 94, 935-941.

29. Alkmim, G. D., Lameiras, F. S., Almeida, F. O. T., 2013. International Nuclear Atlantic Conference. INAC. Recife, PE, Brazil. November 24-29.

30. Gadsden, J. A., 1975. "Infrared Spectra of Minerals and Related Inorganic compounds" Butterworths. USA.

31. Saikia, B. J., 2014. Spectroscopic Estimation of Geometrical Structure Elucidation in Natural $\mathrm{SiO}_{2}$ Crystal. J. Mat. Phys. Chem. Vol. 2, No. 2, 28-33. Res. Sect. B 266, 3075.

32. Saikia, B. J., Parthasarathy, G., Sarmah, N. C., 2008. "Fourier transform infrared spectroscopic estimation of crystallinity in $\mathrm{SiO} 2$ based rocks," Bull. Mater. Sci., 31, 775-779.

33. Abdul-Kader, A. M., Zaki,M. F., El-Badry B. A., 2014. Modified the optical and electrical properties of CR-39 by gamma ray irradiation, J.R.R.A.S., 69,1-6.

34. Abdel Reheem, A.M., Abdel Maksoud, M.I.A., Ashour A.H., 2016. Surface modification and metallization of polycarbonate using low energy ion beam. Rad. Phys. Chem. 125, 171-175.

35. Hatipoglua, M., Helvac1, C., Kibar, R., Çetin, A., Tuncer, Y. and Can, N., 2010. 'Amethyst and morion quartz gemstone raw materials from Turkey: color saturation and enhancement by gamma, neutron and beta irradiation', Radiation Effects and Defects in Solids, Vol. 165, No. 11, 876-888.

36. Tauc, J., Grigorovici, R. and Vancu, A. (1966) Optical Properties and Electronic Structure of Amorphous Germanium. Physica Status Solidi (b), 15, 627-637.

37. Malik, D.M., Kohnke, E.E., Sibley, W.A., 1981. Low-temperature thermally stimulated luminescence of high quality quartz. J. Appl. Phys. 52, 3600-3605.

38. Timar-Gabora, A., 2018. Electron spin resonance characterisation of sedimentary quartz of different grain sizes. Rad. Meas. https://doi.org/10.1016/j.radmeas.2018.06. 023.

39. Martini, M., Spinolo, G., Vedda, A., 1986. Radiation-induced conductivity of asgrown and electrodiffused quartz. J. Appl. Phys. 60, 1705-1708.

40. Mondragon, M.A., Chen, C.Y., Halliburton, L.E., 1988. Observation of a dose-rate dependence in the production of point defects in quartz. J. Appl. Phys. 63, 4937-4941.

41. Voinchet, P., Yin, G., Falguères, C., Liu, C., Han, F., Sun, X., Bahain, J.J., 2013. ESR dose response of the $\mathrm{Al}$ center measured in quartz samples from the Yellow River (China): implications for the dating of Upper Pleistocene sediment. Geochronique 40 (4), 341-347.

42. Tsukamoto, S., Toyoda, S., Tani, A., Oppermann, F. 2015. Single aliquot regenerative dose method for ESR dating using X-ray irradiation and preheat. Radiat. Meas. 81, 9-15.

43. Toyoda, S., Falguères, C., 2003. The method to represent the ESR intensity of the aluminium hole center in quartz for the 
purpose of dating. Adv. ESR Appl. 20, 710.

44. Toyoda, S., 2015. Paramagnetic lattice defects in quartz for applications to ESR dating. Quat. Geochronol. 30, 498-505.

45. Aitken, M. J., 1990. Science-based daring in archaeology. Longman, London.

46. Tsakalos, E., Christodoulakis, J., and Charalambous, L., 2016. The Dose Rate Calculator (DRc) for Luminescence and ESR Dating - a Java Application for Dose Rate and Age Determination. Archaeometry, 58: 347-352.

47. Durcan, J.A., King, G.E., Duller, G.A.T., 2015. DRAC: Dose rate and age calculator for trapped charge dating. Quaternary Geochronology, 28: 54-61.

48. Kreutzer, S., Dietze, M., Burow, C., Fuchs, 379 M.C., Schmidt, C., Fischer, M., Friedrich, J. (2017). Luminescence: 380 Comprehensive Luminescence Dating Data Analysis. R package version 0.7.5.

49. Discher, M., Mauz, B., Martin, Loï., Durcan, J.A., King, G.E., Tsakalos, E., Christodoulakis, J., Lang, A., 2018. Calculating or simulating the dose rate? A comparison, Radiation Measurements, doi: 10.1016/j.radmeas.2018.09.006.

50. Papaefthymiou, H. and M. Psichoudaki, 2008. Natural radioactivity measurements in the city of Ptolemais. Journal of Environmental Radioactivity. 99: 10111017.

51. Fares, S., Hassan, A. K., El-Saeedy, H. I., 2017. Environmental Characterization and Natural Radioactivity Influential on the Mountains of the Red Sea Coast, Egypt. ChemXpress. 2017; 10(1):119. 